\title{
ENTREPRENEUR
}

Jurnal Bisnis Manajemen Dan Kewirausahaan

Program Studi Manajemen Fakultas Ekonomika dan Bisnis Universitas Majalengka

Published every January and July e-ISSN : 2776-2483, p-ISSN: 2723-1941

Available online http://ejournal.unma.ac.id/index.php/entrepreneur

\section{Penerapan Design Thinking Dalam Inovasi Tempat Bertransaksi Jual Beli Barang Pada Toko Online Thrifter.Things}

\author{
Ogi Maulana Firli ${ }^{1}$, Iwan Sukoco ${ }^{2}$, Anang Muftiadi ${ }^{3}$ \\ Program Magister Administrasi Bisnis,Universitas Padjajaran \\ Email: Ogi2001@unpad.ac.id ${ }^{1}$, iwan.sukoco@unpad.ac.id ${ }^{2}$, anang.muftiadi@unpad.ac.id ${ }^{3}$
}

\begin{abstract}
The purpose of this study is to analyze the application of design thinking in designing appropriate solutions and innovations to the problems contained in the online shop thrifter.things, especially on the problem of where to buy and sell transactions (buying and selling platforms). This research method uses descriptive research methods and design thinking methods which are research with the aim of describing a situation or phenomenon that is currently happening by using scientific procedures to solve the problem. The results of this study state that at the Emphatise stage the thrifter.things transaction process is irregular, at the Define stage it is necessary to create only one platform that is used as a special place for transactions, at the Ideate Thifter.things stage you can use the website platform as the main place for buying and selling products, at the Prototype stage because the website is an innovative idea to improve the complexity of the buying and selling transaction process at the Thrifter.things online store which will be used as the only place to transact, and at the Test stage a trial of the use of the website is carried out as a potential land for doing online business.

Keywords: Design Thinking; Website; Online Shop
\end{abstract}




\section{ENTREPRENEUR}

\section{Jurnal Bisnis Manajemen Dan Kewirausahaan}

Program Studi Manajemen Fakultas Ekonomika dan Bisnis Universitas Majalengka

Published every January and July e-ISSN : 2776-2483, p-ISSN: 2723-1941

Available online http://ejournal.unma.ac.id/index.php/entrepreneur

\section{PENDAHULUAN}

Ditengah arus informasi yang semakin deras, masyarakat sudah tidak seharusnya memikirkan batasan jarak, ruang dan waktu dalam melaksanakan kegiatan berkomunikasi, karena pada era informasi yang arusnya sangat deras ini membuat masyarakat tidak perlu lagi bertatap muka untuk bercakap secara lisan maupun tulisan, cukup dengan satu genggaman saja saat ini kita dapat mengakses dan berkomunikasi dengan dunia luas. Internet merupakan buah dari kecocokan antara kecanggihan, kemajuan ilmu pengetahuan, dan teknologi buatan manusia. Rahmadi (2003), yang fungsinya yaitu untuk menyediakan akses untuk layanan telekomunikasi dan berbagai sumber daya informasi untuk membantu segala aspek kehidupan di dunia. Rusdiono (2019). Teknologi internet sudah semakin banyak dimanfaatkan oleh berbagai organisasi, tidak terkecuali oleh organisasi bisnis. Melalui teknologi internet, pelaku bisnis dapat melakukan berbagai kegiatan usaha bisnisnya secara online, dimulai dari proses bertansaksi hingga melakukan promosi. Pelaku bisnis dapat memanfaatkan teknologi internet guna menunjang kegiatan bisnis dimasa yang akan datang salah satunya dengan membangun website. Aziz (2018).

Menurut Rohi Abdullah (2015), Website merupakan sekumpulan halaman yang terdiri dari beberapa laman yang memuat informasi yang disimpan di internet sebagai data digital berupa teks, gambar, audio, video, dan lain-lain. Pemamfaatan website dalam kegiatan penjualan dapat dimamfaatkan menjadi sebuah katalog produk, didalamnya berisi informasi mengenai barang yang dijual seperti klasifikasi jenis, merek, harga dan kondisi barang, sekaligus di dukung dengan informasi stok yang tersedia di gudang secara terkini. Website toko online dapat mempermudah bisnis seperti dalam promosi produk, memberikan informasi tentang produk penjualan kepada konsumen. Batasan dalam pemasaran produk biasanya menjadi penghalang sebuah toko dalam meningkatkan omzetnya, dan buruknya pengendalian barang serta pelaporan manual berdampak negatif pada toko sehingga menyebabkan terhambatnya laporan persediaan dan laporan penjualan.

Thrifter.things merupakan salah satu bisnis berbasis online shop asal Kecamatan Jatinangor, Kabupaten Sumedang yang berdiri pada bulan September 2019. Industri yang bergerak di bidang fashion ini menjual pakaian secondhand untuk pria maupun wanita yang masih layak pakai dan berkualitas tinggi. Sebagai online shop yang masih berkembang, thrifter.things masih harus melakukan beberapa inovasi untuk menunjang keberlangsungan bisnisnya.

Oleh karena itu, peneliti tertarik untuk menganalisis penerapan design thinking dalam merancang solusi dan inovasi yang tepat pada masalah yang terdapat pada online shop thrifter.things terutama pada platform atau tempat transaksi jual belinya, untuk menjadikan hal tersebut dalam meningkatkan performa bisnisnya.

\section{KERANGKA TEORITIS DAN HIPOTESIS}

Design Thinking merupakan titik pusat yang difokuskan pada manusia terhadap sebuah inovasi yang berasal dari perangkat perancang untuk mengintegrasikan kebutuhan masyarakat, misalnya sebuah teknologi yang menurut sudut pandang bisnis juga dapat menjadi nilai pelanggan dan peluang pasar. Kelley \& Brown (2018). Terdapat tiga proses dalam sebuah design 


\section{ENTREPRENEUR}

Jurnal Bisnis Manajemen Dan Kewirausahaan

Program Studi Manajemen Fakultas Ekonomika dan Bisnis Universitas Majalengka

Published every January and July e-ISSN : 2776-2483, p-ISSN: 2723-1941

Available online http://ejournal.unma.ac.id/index.php/entrepreneur

thinking, diantaranya yaitu: 1)Inspirasi, yaitu keandaan yang memotivasi seseorang untuk mencari sebuah solusi atau jalan keluar. 2)Ideasi, merupakan proses untuk menghasilkan, mengembangkan dan menguji sebuah ide yang menjurus pada solusi. 3)Implementasi, yaitu melaksanakan rencana yang telah disusun untuk mencapai tujuannya. Metode design thinking juga yang menggabungkan kebutuhan penggunanya dengan kemampuan teknologi yang mampu menyelesaikan sebuah permasalah termasuk dalam keberhasilan sebuah bisnis. Amalina et al., (2017), Lazuardi \& Sukoco (2019). Dalam merancang sebuah inovasi yang dilakukan dengan metode design thinking, (Kelley \& Brown, 2018) merangcang 5 tahapan untuk memungkinkan penggunanya dalam memperoleh keluaran yang inovatif, diantaranya yaitu:

\section{Empatize}

Ketika sudah mengetahui pengguna yang akan dituju, maka seorang design thinker perlu mengenal lebih jauh dan mengetahui pengalaman, emosi serta situasi penggunanya. Seorang design thinker juga harus menempatkan diri sebagai pengguna sehingga dapat betul-betul memahami kebutuhan penggunanya. Hal ini dapat dilakukan dengan melakukan pendekatan, pengenalan, dan wawancara observasi kehidupan penggunanya.

\section{Define}

Setelah semuanya dipahami oleh design thinker, maka perlunya menggambarkan sebuah ide yang akan menjadi dasar produk atau aplikasi yang akan dibuat. Dengan cara menuliskan beberapa list kebutuhan penggunanya.

\section{Ideate}

Jika sudah mengetahui beberapa list kebutuhan pengguna, maka Langkah selanjutnya yang perlu dilakukan oleh design thinker yaitu menggambar solusi yang dibutuhkan. Hal ini dapat dilakukan dengan melakukan evaluasi bersama tim design dengan menggabungkan kreativitas dari masing-masing designer.

\section{Prototype}

Ide yang sudah ada maka bisa langsung diterapkan ke dalam sebuah uji coba produk atau aplikasi. Penting untuk membuat produk nyata serta skenario penggunaan potensial.

\section{Test}

Eksperimen akan dilakukan dengan pengguna berdasarkan produk atau aplikasi uji coba yang telah dibuat. Masukan dari pengalaman pengguna dengan produk uji coba akan dikumpulkan untuk menciptakan produk yang lebih baik dan meningkatkan produk yang sudah ada.

Hipotesis penelitian ini sebagai berikut: H1: masalah yang sering ditemui pada online shop thrifter.things adalah pada proses transaksi jual beli.

$\mathrm{H} 2$ : perlu adanya satu tempat untuk melakukan proses transaksi

H3 : website merupakan tempat yang cocok untuk dijadikan satu-satunya tempat untuk melakukan proses transaksi.

\section{METODE PENELITIAN}

Penelitian ini menggunakan metode penetian deskriptif yang merupakan sebuah penelitian dengan tujuan mendeskripsikan suatu keadaan atau fenomena yang terjadi saat ini dengan menggunakan prosedur ilmiah untuk memecahkan masalah (sugiyono,2011). Penelitian ini juga menggunakan Design Thinking sebagai metode dan proses pengumpulan data. Pengumpulan data dengan menganalisis dokumen-dokumen seperti buku ilmiah, 


\section{ENTREPRENEUR}

\section{Jurnal Bisnis Manajemen Dan Kewirausahaan}

Program Studi Manajemen Fakultas Ekonomika dan Bisnis Universitas Majalengka

Published every January and July e-ISSN : 2776-2483, p-ISSN: 2723-1941

Available online http://ejournal.unma.ac.id/index.php/entrepreneur

dokumen kebijakan organisasi, dan peraturan perundang-undangan

\section{HASIL DAN PEMBAHASAN}

\section{Emphatise}

Pada tahap ini, dilakukan identifikasi terhadap Thrifter.things dan ditemukan satu masalah yang sering terulang salah satunya yaitu pada proses transaksi pembelian, Thriter.things ini selalu mengupdate barang jualannya setiap 1-2 kali dalam seminggu dan proses pembeliannya yaitu siapa cepat dia dapat karena barang yang dijual persatu barang itu hanya ada satu model dan satu ukuran, sehingga kerap sering terjadi perebutan barang meski jadwal upload foto produk dan waktu transaksi sudah di jadwalkan, pemilik online shop sering disalahkan karena keterlambatan pembeli yang kalah saing dengan pembeli lain yang kadang dinilai curang atau sering dituduh barangnya sudah di keep terlebih dahulu oleh pemesan lain, ditambah tempat transaksi jual beli terbagi dalam 3 platform, diantaranya $\quad$ yaitu Direct Message (DM) Instagram, WhatsApp, dan Shoppe, sehingga hal tersebut dinilai membingungkan baik bagi owner maupun konsumen karena barang yang dijual hanya ada satu produk dari satu model dan satu ukuran.

\section{Define}

Berdasarkan analisis yang dilakukan pada tahap empathize, di tahap define ini akan menentukan jenis masalah apa yang harus diselesaikan pada Thrifter.things. Masalah proses transaksi pada jual - beli online shop thrifter.things, sebaiknya thrifter.things perlu membuat satu platform saja yang dijadikan tempat jual beli satu-satunya barang yang mereka jual.

\section{Ideate}

Berdasarkan hasil analisis permasalahan dari tahap emphatize dan define dapat disimpulkan bahwa Thrifter.things harus memperhatikan untuk merapihkan pada tata cara proses pembelian di toko onlinenya, ide yang akan dikembangkan yaitu Thrifter.things dapat menggunakan platform Website Sebagai alat atau satu-satunya tempat jual beli pada toko onlinenya, tidak usah ada penjualan via DM instagram maupun WA dan Shoppe.

\section{Prototyping}

Website merupakan inovasi ide untuk memperbaiki kerumitan proses transaksi jual beli pada toko online Thrifter.things yang akan dijadikan sebagai satu-satunya tempat bertransaksi. Pemamfaatan website dalam kegiatan penjual juga dapat dimamfaatkan menjadi sebuah katalog produk, yang didalam berisi informasi mengenai barang yang dijual seperti klasifikasi jenis barang, merek barang, harga dan juga kondisi barang, sekaligus di dukung dengan informasi stok yang tersedia di gudang secara terkini. Aziz (2018). Kemudian platform Instagram dapat digunakan sebagai media Promosi dan Informasi untuk toko online Thrifter.thing, dan WhatsApp bisa tetapi digunakan sebagai Call Center atau Costumer Care.

5. Test

Tahap ini merupakan tahap pengujian terhadap prototype. Inovasi yang diciptakan oleh Thrifter.things dinilai dapat menjadi solusi untuk mempermudah jalannya proses transaksi jual beli yang merupakan barang limited, sehingga diharapkan dengan adanya Website pada toko online ini akan memberikan pengalaman yang berbeda untuk para konsumen, karena konsumen hanya akan bisa memesan produk Thrifter.things dari satu platform, dan akan mempermudah juga ketika akan memperebutkan suatu barang, karena prosesnya bisa ketahui langsung oleh 


\section{ENTREPRENEUR}

Jurnal Bisnis Manajemen Dan Kewirausahaan

Program Studi Manajemen Fakultas Ekonomika dan Bisnis Universitas Majalengka

Published every January and July e-ISSN : 2776-2483, p-ISSN: 2723-1941

Available online http://ejournal.unma.ac.id/index.php/entrepreneur

konsumen berbeda dengan saat pembelian via WhatsApp yang konsumennya tidak mengetahui uratan antrian pembelian barang secara jelas.

\section{SIMPULAN DAN IMPLIKASI}

Penggunaan design thinking dapat menumbuhkan inovasi dalam penciptaan produk melalui beberapa tahapan, diantaranya yaitu pada tahap Emphatize proses transaksi thrifter.things tidak teratur, pada tahap Define hanya perlu dibuat satu platform yang digunakan sebagai tempat khusus bertransaksi, pada tahap Ideate Thifter.things anda dapat menggunakan platform website sebagai tempat utama jual beli produk, pada tahap Prototype karena website merupakan ide inovatif meningkatkan kompleksitas proses transaksi jual beli di Thrifter. Toko online yang akan dijadikan satu-satunya tempat bertransaksi, dan pada tahap Test dilakukan uji coba penggunaan website sebagai lahan potensial berbisnis online. Proses perencanaan solusi untuk mencari solusi menjadi lebih mudah, transparan, dan terstruktur berkat design thinking, dan dapat berakibat mudahnya tata cara proses transaksi pembelian produk di toko online thriftter.things.

\section{DAFTAR PUSTAKA}

Amalina, S., Wahid, F., Satriadi, V., Farhani, F. S., \& Setiani, N. (2017, August). Rancang Purwarupa Aplikasi UniBook Menggunakan Metode Pendekatan Design Thinking. In Seminar Nasional Aplikasi Teknologi Informasi (SNATi).

Aziz, E. S. N., \& Yanto, H. (2018, August). Perancangan Aplikasi Penjualan Berbasis Web Pada Branded Thrift Shop Pontianak. In ENTER (Vol. 1, No. 1, pp. 492-503).
Baskoro, M. L., \& Haq, B. N. (2020). Penerapan metode design thinking pada mata kuliah desain pengembangan produk pangan. IKRA-ITH HUMANIORA: Jurnal Sosial Dan Humaniora, 4(2), 83-93.

Hussein, A. S. (2018). Metode Design Thinking untuk Inovasi Bisnis. Universitas Brawijaya Press.

Lazuardi, M. L., \& Sukoco, I. (2019). Design Thinking David Kelley \& Tim Brown: Otak Dibalik Penciptaan Aplikasi Gojek. Organum: Jurnal Saintifik Manajemen dan Akuntansi, 2(1), 1-11.

Maulana, F., \& Sukoco, I. (2020). Penggunaan Design Thinking Dalam Inovasi Kemasan Produk Sebagai Strategi Membangun Sebuah Merek Pada Merek Bangflo. Business Preneur: Jurnal Ilmu Administrasi Bisnis, 2(2), 58-62.

Ramadhanti, A. (2020). Strategi Pengembangan Bisnis Pada Thrift's Trove. Jurnal Ilmiah Mahasiswa FEB, $8(2)$.

Rusdiono, R. (2019). Peran Media Sosial Sebagai Upaya Pemasaran Bisnis Online Shop Pada Online Shop Antler MakeUp@ antler. makeup. Widya Cipta: Jurnal Sekretari dan Manajemen, 3(2), 195-202.

Saad, M. I. (2020). Otodidak Web Programming: Membuat Website Edutainment. Elex Media Komputindo.

Wahyudin, W., Herwanto, D., \& Nugraha, B. Redesain Tata Letak Taman Bermain Outdoor Santri Raudhatul Atfal dengan Metode Design Thinking yang Ergonomis. Performa: Media Ilmiah Teknik Industri, 19(1).

Zaki, A., \& Sukoco, I. (2018). Use of Design Thinking at Digital Tecnology Consultant Company Indie Labtek Bandung. AdBispreneur, 3(2), 123-129. 